\title{
POLICHLORINTŲ DIBENZO-P-DIOKSINŲ IR POLICHLORINTŲ DIBENZOFURANŲ SKLAIDA APLINKOS ORE, VILNIAUS MIESTE
}

\author{
Vigilija Cidzikienė, Renata Chadyšienė, Paulius Miškinis, Artūras Jukna \\ Vilniaus Gedimino technikos universitetas
}

Raktažodžiai: antropogeniniai procesai, polichlorinti dibenzo-p-dioksinai, polichlorinti dibenzofuranai, toksinio ekvivalentiškumo faktorius, pusėjimo trukmè, organinių junginių pernaša ore.

\begin{abstract}
Santrauka
Polichlorinti dibenzo-p-dioksinai ir polichlorinti dibenzofuranai $(\mathrm{PCDD} / \mathrm{F})$ toksiniai organiniai junginiai atsiranda medžiagų degimo metu išsiskiriančiuose dūmuose, o patekę ị organizmą - kaupiasi poodiniame riebaliniame sluoksnyje. Junginiai pasižymi santykinai ilga pusėjimo trukme, tad kartu su dūmais atsiradę atmosferoje oro srovių gali būti nunešti didelius atstumus nuo juos emitavusių šaltinių. Nerimą keliantis junginių kiekio ore didejjimas šiandien jau nustatomas specialiais tyrimų metodais bei jautriais prietaisais, tačiau mažas jų dozes užterštoje aplinkoje, maiste ar žmogaus organizme vis dar labai sunku aptikti. 2017 $\mathrm{m}$. gegužès ir rugpjūčio mèn. $\mathrm{PCDD} / \mathrm{F}$ koncentracija Vilniaus mieste atitinkamai sieke $0,03 \mathrm{pg} / \mathrm{m}^{3}$ ir 0,016 $\mathrm{pg} / \mathrm{m}^{3}, 2018 \mathrm{~m}$. vasario mèn. padidejo iki $0,52 \mathrm{pg} / \mathrm{m}^{3}$, o $2018 \mathrm{~m}$. spalio mèn. vèl sumažèjo iki $0,015 \mathrm{pg} /$ $\mathrm{m}^{3}$. Išmatuotos vertès Vilniaus mieste koreliuoja su koncentracijomis, nustatytomis Vakarų Europos šalyse. Pagal Europos Sajungos ir Lietuvos Respublikos galiojančius teisès aktus $\mathrm{PCDD} / \mathrm{F}$ metinè ribinè vertè turètų neviršyti $100 \mathrm{pg} / \mathrm{m}^{3}$, tačiau vis dar nèra nei nacionalinėse, nei ES direktyvose nustatyta šių toksiškų junginių paros ribinè vertè. Pasaulio sveikatos organizacija (PSO) rekomenduoja $-3 \cdot 10^{6} \mathrm{pg} / \mathrm{m}^{3}$. Mūsų atlikti eksperimentiniai ir teorinio modeliavimo tyrimai leidžia įvertinti dabartinę PCDD/F junginių koncentraciją ore ir prognozuoti jų kaitą, ịvertinant naujų taršos šaltinių atsiradimą.
\end{abstract}

\section{Ivadas}

Polichlorinti dibenzo-p-dioksinai (PCDD) ir polichlorinti dibenzofuranai (PCDF) - dvi pusiau lakiujų organinių junginių grupès. Jie stabilūs aplinkoje, ilgai pernešami atmosferoje ir gali būti akumuliuojami ekosistemoje per maisto grandinę. $\mathrm{PCDD} / \mathrm{F}$ pasižymi dideliu toksiškumu: gali sukelti širdies sutrikimus, sutrikdyti imuninès, endokrininès sistemos veiklą, moterų reprodukcinès sveikatos problemas (ilgesnès trukmès menstruacijos, ankstyva menopauzè), sąlygoti skirtingų vèžio formų išsivystymą, odos bẻrimus [1]. Poveikị žmogaus sveikatai lemia daugelis faktorių: teršalų koncentracija, organizmo ekspozicijos užterštoje aplinkoje laikas, organizmo amžius ir sveikatos būklè ir kt. Aiškesniam toksiškumo vertinimui priimtas toksinio ekvivalentiškumo faktorius (TEF), kurio galima didžiausia verte - 1 . Pasaulio sveikatos organizacija (PSO) rekomenduoja reguliariai vertinti teršalų galimą poveikį žmogui ir gyvenimo kokybei.

Dioksinų emisiją iš nepramoninių šaltinių sunku nustatyti ir kiekybiškai tiksliai ịvertinti. Šaltinių gali būti keli, o juose medžiagų degimo sąlygos ir teršalų susidarymo procesai nekontroliuojami. Išskirtinai dideli šios rūšies teršalų šaltiniai - atsitiktiniai gaisrai, dyzelino degimas automobiliu varikliuose, pentachlorfenoliu užterštų medienos produktų ir buitinių atliekų neteisètas deginimas [2]. Pramonès įmonių veikla sukurtų PCDD/F dujų emisija periodiškai išmatuojama, o valymo įrenginiai - atnaujinami. Tad pramoniniai teršalų šaltiniai sukontroliuojami, įmonėms prisilaikant teisès aktais reglamentuotų išmetamų teršalų normų, kitaip nei nepramoninių šaltinių [3]. Pastarujų emisijos lygị labiausiai veikia gyventojų socialinio sąmoningumo laipsnis [4].

Pagrindinis $\mathrm{PCDD} / \mathrm{F}$ šaltinis - antropogeniniai procesai, susiję su kuro deginimu. PCDD/F susidarymą sąlygoja cheminès reakcijos tarp organinių junginių ir chloro. Išskirtinai pažymètini teršalų šaltiniai - atliekų deginimas, metalurgijos pramone, dyzeliniais varikliais varomos transporto priemonès [5], akmens anglies ir medienos katilinès, gaisrai, fejerverkai [6].

Atlieku degimo proceso metu susidaro dideli kiekiai $\mathrm{PCDD} / \mathrm{F}$ dèl jose esančių chloro ir vario didelio kiekio [7]. Pastaruoju metu kietujų atliekų deginimas vis dažniau tampa viena iš strateginių atliekų tvarkymo perspektyvių alternatyvų [8]. Nors PCDD/F paprastai susidaro daugelio degimo procesų metu, kaip šalutinis produktas, pastaruoju 
metu akcentuojami kaip vienas pagrindinių išmetamų teršalų [9]. Deginimas, palyginus su kitais atliekų tvarkymo būdais (konservavimo sąvartynuose, biologinio perdirbimo ir kt.), turi daug privalumų. Sudegusio produkto nuo 85 iki $90 \%$ mažesnis tūris, nuo 5 iki $80 \%$ mažesnè masè [10]. Produkto deginimo metu išsiskirianti šiluma gali būti konvertuota ị kitas energijos rūšis. Tyrimų rezultatai [11,12] rodo, kad šiuolaikinių valymo įrenginių dèka atliekų deginimo jègainès labai mažai veikia aplinką. Europoje ribinès vertès - $100 \mathrm{pg} /$ $\mathrm{m}^{3}$ [13]. Išsivysčiusių Europos Sajungos šalių aplinkos ore kasmet registruojama vis mažesnė PCDD/F koncentracija, ypač patvirtinus ir prièmus išmetalus reguliuojančius nacionalinius ir tarptautinius teisès aktus [5]. Didžiojoje Britanijoje atlikto tyrimo metu nerasta vienareikšmių irodymų, jog tokių jègainių išmetalai daro neigiamą poveikị naujagimių ar gyventojų, reziduojančių netoli jẻgainès, sveikatai [14]. Tačiau dèl didelio minètų teršalų toksiškumo išsivysčiusių šalių visuomenę labai neramina naujų jègainių šalia urbanizuotų teritorijų atsiradimas, nors projektuojant jègaines tikimasi, jog ị aplinkos orą patenkančios PCDD/F koncentracijos neviršys $3 \cdot 10^{6} \mathrm{pg} \mathrm{I}-\mathrm{TEQ} / \mathrm{m}^{3}$. Teršalų koncentracijai sumažinti atliekų deginimo įmonèse dūmai filtruojami specialiais filtrais bei palaikoma aukštesnè nei $850^{\circ} \mathrm{C}$ degimo temperatūra. Deginant atliekas aukštesnèje nei $850^{\circ} \mathrm{C}$ temperatūroje didžioji dioksinų dalis skyla ị anglies dioksidą, vandenị ir vandenilio chloridą [13].

Teršalų pernaša atmosferoje oro srautais lemia PCDD/F pernašą i sausumos ir vandens ekosistemas [15]. Net ir pastebimai mažejant absoliutiniam kiekiui teršalų ore, pavojus visiškai neišnyksta. $\mathrm{PCDD} / \mathrm{F}$ pusejjimo trukmè yra $5-15$ metų [16], tad jų patekimo ị maisto grandinę tikimybè išlieka labai didelè. Kvejpuojant PCDD/F užterštu oru, ị žmogaus organizmą pateks vidutiniškai tik $1 \%$ nuo visos teršalo koncentracijos ore, tačiau reziduojant arti taršos šaltinio, ta dalis gali sudaryti ar net viršyti paros normą [17].

$\mathrm{PCDD} / \mathrm{F}$ teršalu koncentracija konkrečioje vietovejje ore priklauso nuo tyrimo metu buvusių meteorologinių sąlygų [18], taršos pernašos mechanizmų, nusédimo ant sausumos/ vandens paviršiaus greičio [19]. Sezoniškumo aspektas taip pat svarbus: PCDD/F kiekis aplinkos ore didesnis šaltuoju sezono metu [20].

PCDD/F koncentracijos pavieniai tyrimai ir/ar šios rūšies taršos monitoringas Lietuvoje iki šiol nebuvo atliekamas. Turint mintyje aukštą tyrimų kainą, reikalinga nacionalinè $\mathrm{PCDD} / \mathrm{F}$ tyrimų programa bei taršos monitoringas visoje šalyje, ore, dirvožemyje, vandenyje urbanizuotose, pramonès ir kaimo vietovèse. Kaip seka iš Europos Sajungos šalyse atliekamų tyrimų rezultatų, Lietuvoje pagrindinis PCDD/F šaltinis - buitinių atliekų savavališkas deginimas netinkamomis sąlygomis, t. y. neužtikrinant aplinkosauginių reika- lavimų. Tad šalies gyventojų žemas socialinis sąmoningumas gali taip pat sąlygoti teršalų koncentracijos aplinkoje pokyčius [21].

Siame darbe siekiama ịvertinti PCDD/F koncentraciją ore Vilniaus Lazdynų seniūnijoje. Sutinkamai su miesto valdžios planais, Lazdynų seniūnijoje bus pastatyta didelio efektyvumo kogeneracinè jègainè, deginanti buitines atliekas. Tad darbe siekiama ištirti PCDD/F teršalų koncentraciją ore dar iki jègainès eksploatacijos pradžios ir nustatyti potencialius šios rūšies teršalų dabartinius pagrindinius šaltinius (t. y. motorizuoto transporto ir gyventojų veiklos sąlygotus PCDD/F teršalų kiekius) Vilniaus mieste, įskaitant ir priemiesčio zoną, besiribojančią su Lazdynų seniūnija.

Darbo tikslas: remiantis tyrimų rezultatais, būsimai kogeneracinei elektrinei dirbant nominaliu režimu, bus siekiama nustatyti visų taršos šaltinių integralinị poveikị Vilniaus miesto Lazdynų seniūnijos zonoje.

\section{Metodika}

PCDD/F koncentracija ore, vandenyje, nuosedose, augaluose ir gyvūnuose ịvertinama eksperimentiniais metodais. Mūsų darbe aplinkos oro kokybe tirta mobiliojoje tyrimų laboratorijoje, atliekamų tyrimų metu lokalizuotoje automobilių stovejjimo aikštelèje, šalia Šiltnamiu g. ir Bukčių g. sankryžos. Artimiausia laboratorijai miesto magistralè, ịtaki tyrimų rezultatams - Oslo g. (transporto srautas $\sim 100000$ transporto priemoniu/parą), nutolusi nuo matavimų mobilios laboratorijos $\sim 400 \mathrm{~m}$. šiaurès kryptimi. Papildomi veiksniai, galèję turèti ịtakos matavimų rezultatams - tai ị stovejjimo aikštelę ịvažiuojančių ar išvažiuojančių transporto priemonių išmetalai, požeminès automobilių stovejjimo aikštelès védinimo angų, lokalizuotų 5-10 m atstumu nuo atliekamų matavimo vietos, išmetalai, o taip pat UAB „Vilniaus energija“" elektrinès jègainès, rytų kryptimi nutolusios $\sim 1 \mathrm{~km}$. atstumu nuo tyrimų laboratorijos.

Tyrimams reikalingi aplinkos oro 4 bandiniai paimti 2017 m. gegužès ir rugpjūčio mèn. bei $2018 \mathrm{~m}$. vasario ir spalio mèn. Bandinių cheminès sudèties tyrimai atlikti Estijos aplinkos tyrimų centro Centrineje tyrimų laboratorijoje. Kiekvienas iš aplinkos oro bandinių, formuotas po 24 val. Digitel DHA-80 pakopiniu didelès apimties aerozolio èmikliu. PCDD/F kiekis aplinkos oro bandinyje nustatomas dujų emisijos vakuume metu, naudojant izotopų skiedimo metodą, kartu su aukštos skiriamosios gebos dujų chromatografija ir aukštos skiriamosios gebos masių spektrometrija.

\section{Rezultatai}

Vakarų Europos šalyse dioksinų koncentracija ore mažesnè, nei kitose Pasaulio šalyse. Be to, urbanizuotų teritorijose eksperimentiškai išmatuotos vertès artimos gautoms 
neurbanizuotose teritorijose. Tai leidžia daryti išvadą, jog Europoje taršos šaltinių skaičius ir emisijos apimtys palaipsniui mažeja [22]. Mūsų gauti tyrimų rezultatai patvirtina šią išvadą (1 pav.). Palyginus su kitomis ES šalimis (1 pav.), Vilniuje mūsų išmatuotos dioksinų vertès, įvertinus pramonès objektų, transporto bei gyventojų veikla sukurtą teršalų emisiją, net $80 \%$ mažesnès.

$\mathrm{PCDD} / \mathrm{F}$ junginius sudaro 17 -os junginių ịvairūs mišiniai. Toksinis $\mathrm{PCDD} / \mathrm{F}$ ekvivalentas (TEF) išreiškia santykini junginio toksiškumą, labiausiai toksiškų TCDD ir PeCDD nagrinèjamos grupès junginių atžvilgiu. Vertinant ịvairių PCDD/F vienos grupès junginių toksiškumą, TEF sunormuojamas ị vienetą, t. y. toksiškiausio tarpusavyje lyginamos grupès junginio, vertinant masès vienetui, TEF $=1$ (1 lentelè). Norint apskaičiuoti bet kurio kito tos pačios grupès junginio toksinị ekvivalentą, vertinamojo junginio vienetinès masès toksinis ekvivalentas dauginamas iš tiriamojo junginio kiekio, aptinkamo aplinkos ore kartu su kitais junginiais.

Pagrindiniai PCDD/F junginiai, aptinkami šiltuoju metų laiku 1,2,3,4,6,7,8-HpCDF, 1,2,3,4,6,7,8,9-HpCDF ir OCDD. Jų kiekis tiriamajame bandinyje sudare atitinkamai $21 \%, 11 \%$ ir $25 \%$. Eksperimentiškai nustatyta, jog šaltuoju metų laiku aplinkos ore Lazdynų seniūnijoje dažniausiai aptinkamos 1,2,3,4,6,7,8-HpCDF, OCDD ir OCDF medžiagos, kurių masė bandinyje sudare $9 \%, 11 \%$ ir $16 \%$. Kitų laboratorijų nustatyta [23], jog daugiausia 2,3,4,7,8-PeCDF ir 1,2,3,7,8-PeCDD medžiagų išsiskiria anglies ir medienos degimo proceso metu. Tad mūsų gauti rezultatai leidžia daryti išvadą, jog Lazdynų seniūnijoje šaltuoju metų laiku dioksinų

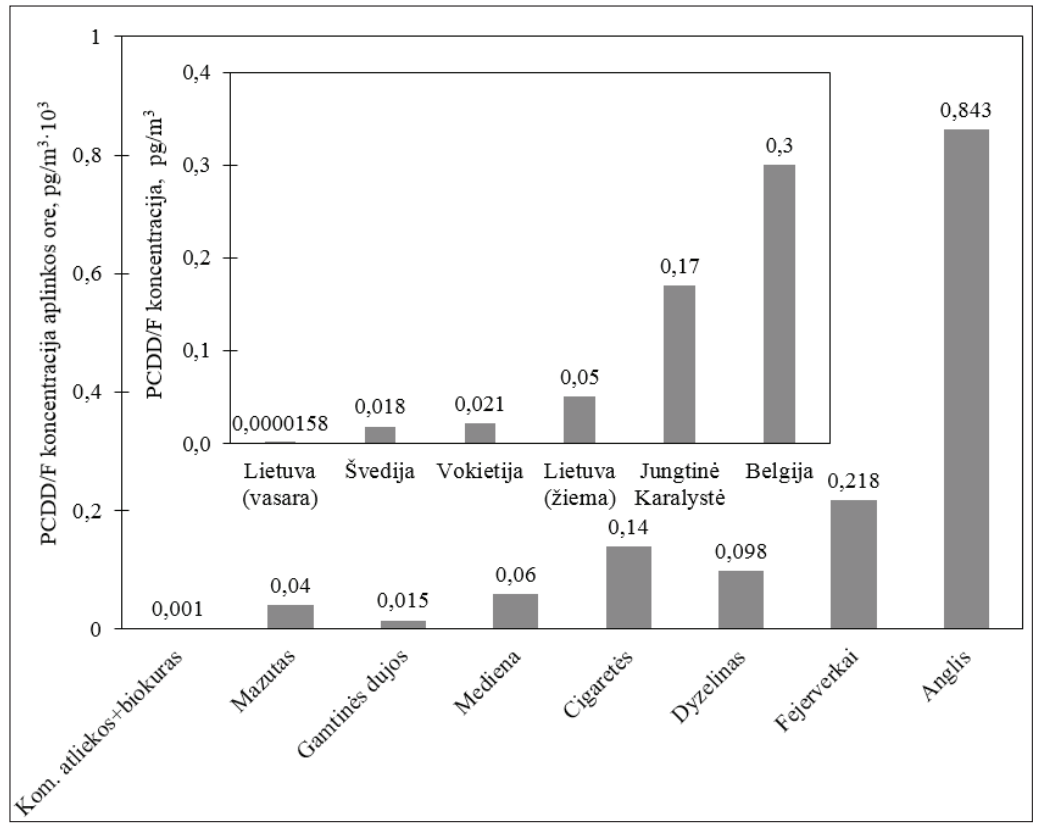

1 pav. Pagrindiniai PCDD/F šaltiniai ir jų sukuriama teršalų koncentracija pg/TEQ, $\mathrm{m}^{-3}$, eksperimentiškai išmatuota aplinkos ore, ir PCDD/F koncentracijos išmatuotos aplinkos ore Lietuvoje, Vilniuje, Lazdynų seniūnijoje šiltuoju ir šaltuoju laikotarpiu bei jų palyginimas su dioksinų koncentracija išmatuota kitose Europos šalyse (duomenys palyginimui paimti iš ịvairių šaltinių). ir furanų teršalų dali aplinkos ore gali sukurti namų ūkiai.

$\mathrm{PCDD} / \mathrm{F}$ teršalų kiekio priklausomybė nuo sezoniškumo kelia ypatingą tyrèjų susidomejjimą. Gauti rezultatai leidžia atspèti potencialius teršalų šaltinius (pvz., sezoninis patalpų šildymas, specifiniai atmosferos oro savivalos procesai (fotolizè). PCDD/F kiekio ore ir sezoniškumo koreliacija stebèta ir kitų autorių, kaimyninèse šalyse [24]. Jų gautų rezultatų pagrindu suformuluotos išvados, jog medienos degimo temperatūrai žemèjant, sumažeja medienos degimo efektyvumas ir pastebimai padidejja PCDD/F medžiagų emisija [25].

Didesni dioksinų ir furanų kiekiai aplinkos ore šaltuoju metų laiku stebimi tik prasidejjus šildymo sezonui (t. y. pradejus deginti medieną/angli). Tačiau, nereikia pamiršti, jog šaltuoju metų laiku mažiau efektyvi oro savivala ir mažiau veiksminga teršalų sklaida aplinkos ore bei nusédimas ị dirvožemị.

1 lentelè. $\mathrm{PCDD} / \mathrm{F}$ junginių pusèjimo trukmè ir toksinio ekvivalentiškumo faktorius (TEF).

\begin{tabular}{|l|c|c|}
\hline $\begin{array}{l}\text { PCDD/F } \\
\text { junginys }\end{array}$ & $\begin{array}{c}\text { Pusėjimo } \\
\text { trukmé, } \\
\text { metai }\end{array}$ & $\begin{array}{c}\text { TEF, } \\
\mathbf{2 0 0 5}\end{array}$ \\
\hline $2,3,7,8-\mathrm{TCDD}$ & 14 & 1 \\
\hline $1,2,3,7,8-\mathrm{PeCDD}$ & 16 & 1 \\
\hline $1,2,3,4,7,8-\mathrm{HxCDD}$ & 14 & 0,1 \\
\hline $1,2,3,6,7,8-\mathrm{HxCDD}$ & 14 & 0,1 \\
\hline $1,2,3,7,8,9-\mathrm{HxCDD}$ & 7 & 0,1 \\
\hline $1,2,3,4,6,7,8-\mathrm{HpCDD}$ & 4 & 0,001 \\
\hline OCDD & 8 & 0,0003 \\
\hline $2,3,7,8-\mathrm{TCDF}$ & 3 & 0,1 \\
\hline $1,2,3,7,8-\mathrm{PeCDF}$ & 5 & 0,03 \\
\hline $2,3,4,7,8-\mathrm{PeCDF}$ & 20 & 0,3 \\
\hline $1,2,3,4,7,8-\mathrm{HxCDF}$ & 8 & 0,1 \\
\hline $1,2,3,6,7,8-\mathrm{HxCDF}$ & 10 & 0,1 \\
\hline $1,2,3,7,8,9-\mathrm{HxCDF}$ & - & 0,1 \\
\hline $2,3,4,6,7,8-\mathrm{HxCDF}$ & 11 & 0,1 \\
\hline $1,2,3,4,6,7,8-\mathrm{HpCDF}$ & 4 & 0,01 \\
\hline $1,2,3,4,6,7,8,9-\mathrm{HpCDF}$ & 7 & 0,01 \\
\hline OCDF & 2 & 0,0003 \\
\hline
\end{tabular}


Visų PCDD tyrimų atveju OCDD junginys dominuoja, tačiau santykis tarp 1,2,3,4,6,7,8-HpCDD ir OCDD junginiu kiekių (masès vienetais) bandinyje panašus. PCDD dominuoja 2,3,7,8-TCDD; 1,2,3,7,8-PeCDD junginiai, kurie vidutiniškai sudaro atitinkamai 42 $\%$ ir $32 \%$ bandinyje, paimtame šiltuoju medų laiku, ir apie $52 \%$ ir $33 \%$, paimtame šaltuoju metu laiku (2 pav.).

Remiantis mūsų ir kitų autorių [26] gautais rezultatais galima daryti prielaidą, jog šiltuoju metų laiku labiausiai tiketina, jog pagrindinis PCDD/F šaltinis - dyzelinių variklių išmetalai. Tai paaiškintų gautus rezultatus (2 pav.), ypač jų dalị, susijusią su santykinai didele teršalų emisija šiltuoju metų laiku. Labai tikètina, kad 2,3,7,8TCDD ir 1,2,3,7,8-PeCDD junginių atsiradimą lèmé šalia matavimų laboratorijos esančioje automobilių stovejjimo aikštelè bei netoliese esančiu greitkeliu judančios, dyzelinu varomos transporto priemonès. PCDF junginiuose dominuoja 2,3,4,7,8-PeCDF, $1,2,3,4,7,8-\mathrm{H} \times \mathrm{C}$ D F, $1,2,3,6,7,8-\mathrm{H} \times \mathrm{C} \mathrm{D} F$, $1,2,3,7,8,9-\mathrm{H} \times \mathrm{C} \mathrm{DF}$ i $\mathrm{r}$ 2,3,4,6,7,8-HxCDF, kurių toksinis ekvivalentas oro bandinyje šiltuoju metų laikotarpiu vidutiniškai sudare atitinkamai $30 \%, 13 \%, 13 \%, 9 \%$, ir $13 \%$. Tų pačiu junginių santykinis kiekis (toksinio ekvivalento atžvilgiu) bandinyje šaltuoju metų laikotarpiu padidejo ir atitinkamai sudare $48 \%, 5 \%, 12 \%, 8 \%$ ir 12 $\%$. Savo toksiniu ekvivalentu išskirtina 2,3,4,7,8 PeCDF medžiaga. Jos dalis aplinkos oro bandiniuose gali sudaryti net $20-40 \%$.

Aplinkos oro kokybès Europoje, Amerikoje, Japonijoje ir Australijoje tyrimų rezultatai taip pat patvirtina, jog PCDF junginiu

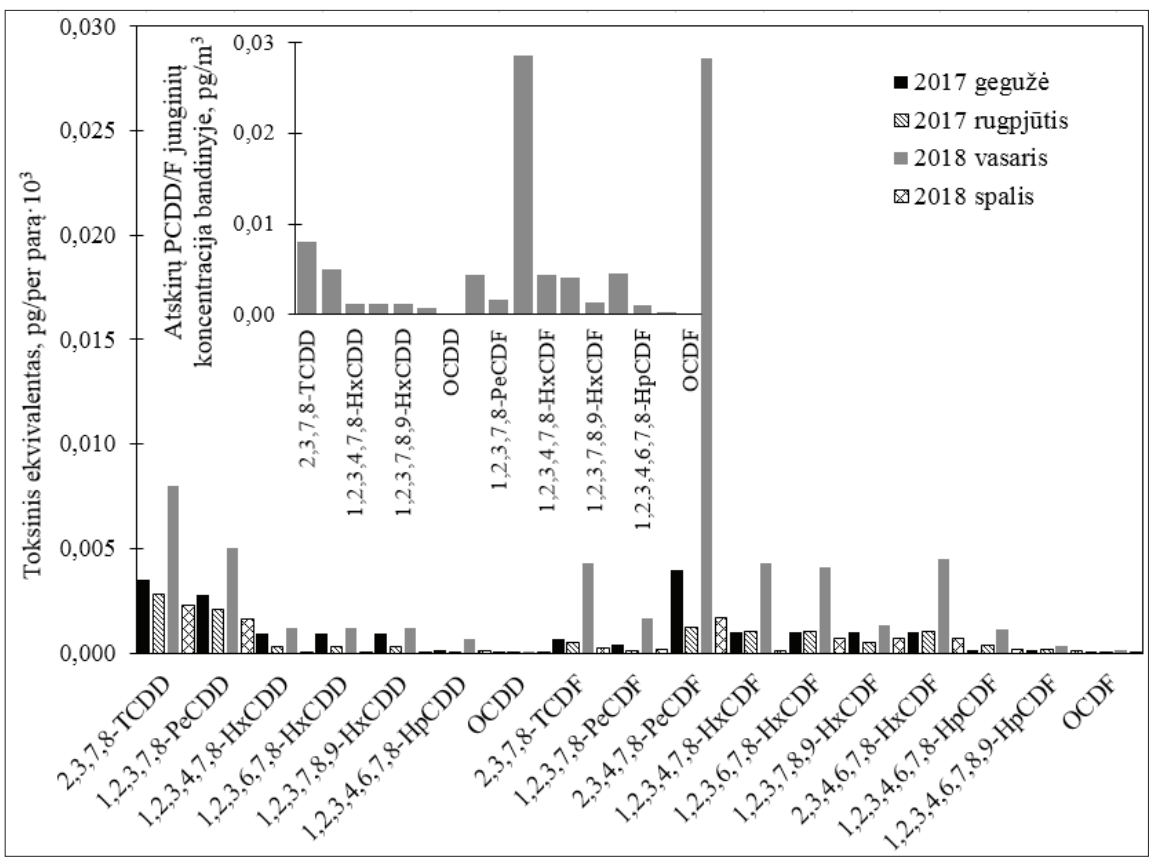

2 pav. Ivvairių PCDD/F junginių toksinis ekvivalentas, kurį skaičiuojant atsižvelgta ị kiekvieno junginio toksiškumą bei jo masès procentinę dalį, ir PCDD/F junginiai bei jų kiekiai išmatuoti tiriamajame bandinyje suformuotame šaltuoju sezonu aplinkos ore Lazdynų seniūnijoje, Vilniuje.

toksinis ekvivalentas gali sudaryti beveik $50 \%$ nuo viso bandinio toksinio ekvivalento [27]. Detaliau analizuojant șsitikinta, jog TeCDD/F ir PeCDD/F giminingi junginiai bandinyje gali sudaryti $50 \%$ toksinio ekvivalento. Tačiau dažnai giminingų junginių kiekiai bandinyje būna artimi ar mažesni už slenkstinę tyrimų įrangos jautrio ribą. Tuomet toksinis ekvivalentas ịvertinamas (taip pat ir šiame darbe) laikant, jog faktinis medžiagos kiekis bandinyje sudaro pusę tyrimo įrangos jautrio ribinès vertès. Tai vienas iš pagrindinių faktorių, lemiančių PCDD/F medžiagą sudarančių junginių toksinio ekvivalento eksperimentinių tyrimų/skaičiavimų paklaidą.

Nustatyta, kad PCDF junginių toksinis ekvivalentas aplinkos oro bandinyje gali sudaryti per $62 \%$ šiltuoju metu laiku ir $72 \%$ - šaltuoju metu. Tuomet PCDD junginių šis parametras tesiekia atitinkamai $38 \%$ ir $28 \%$. Šaltuoju metų laiku, pradejjus šildymo sezoną, PCDD/F medžiagų šaltinių skaičius išauga. Kartu su transporto priemoniu varikliuose sudegusio dyzelino produktais aplinkos ore atsiranda namų ūkių šildymui naudojamo kuro degimo produktai. Atsižvelgus ị ilgą dioksinų ir furanų pusèjimo trukmę (pvz., TCDD pusejiimo trukmè - net keleri metai), medžiagos metabolizmas labai lètas. Labai ilgą pusẻjimo trukmę turintys dioksinų grupės teršalai, tikètina, gali kauptis gyvuose organizmuose, nors jų poveikis žmonių sveikatai dar galutinai neištirtas. Pagrindinè priežastis - tokių patvarių organinių teršalų poveikio tyrimui reikalingi ypač jautrūs žymenys [28].

\section{Išvados}

1. Potencialiai pavojingi žmogaus sveikatai dioksinai ir furanai (PCDD/F) aplinkos ore susidaro antropogeninių procesų metu. PCDD/F sudaro įvairių toksinių ekvivalentų organiniai junginiai, iš kurių aukščiausiais toksinio ekvivalento rodikliais pasižymi 2,3,7,8-TCDD ir 1,2,3,7,8-PeCDD junginiai. 
2. Pagrindiniai $\mathrm{PCDD} / \mathrm{F}$ šaltiniai - sausumos/jūrų/oro transporto priemonių ir namų ūkio išmetalai. Šaltinių emisijos intensyvumą didele dalimi lemia ne tik kuro degimo sąlygos, kurias optimizavus galima sumažinti $\mathrm{PCDD} / \mathrm{F}$ patekimą i i aplinkos orą, bet taip pat ir visuomenès sąmoningumo stoka, pasireiškianti savavališku, netinkamu buitinių atlieku deginimu.

3. Aplinkos ore Vilniuje, Lazdynų seniūnijoje, PCDD/F medžiagų kiekis nedaug tesiskiria nuo kiekių, eksperimentiškai išmatuotų aplinkos ore Vakarų šalyse. Žmogaus sveikatai vis dar nepavojinga PCDD/F metinè dozè gali būti pasiekta, jei šios rūšies teršalų koncentracija aplinkos ore neviršys 100 $\mathrm{pg} / \mathrm{m}^{3}$. Vienos paros ribinè verte dar nenustatyta nei nacionalinėse, nei ES direktyvose. PSO rekomendacija $-3 \cdot 10^{6} \mathrm{pg} / \mathrm{m}^{3}$.

4. $2017 \mathrm{~m}$. gegužès ir rugpjūčio mèn. PCDD/F koncentracija aplinkos ore Vilniuje, Lazdynų seniūnijoje, siekè atitinkamai $0,03 \mathrm{pg} / \mathrm{m}^{3}$ ir $0,016 \mathrm{pg} / \mathrm{m}^{3}, 2018 \mathrm{~m}$. vasario mèn. $-0,52 \mathrm{pg} / \mathrm{m}^{3}, 2018 \mathrm{~m}$. spalio mèn. $-0,015 \mathrm{pg} / \mathrm{m}^{3}$.

5. Atsižvelgiant ị aukšto toksinio ekvivalento junginių ilgą gyvavimo trukmę ir nuolat kintančias aplinkos oro sąvivalos sąlygas, PCDD/F emisijas rekomenduojama kontroliuoti ir, jei įmanoma, sumažinti.

\section{Literatūra}

1. European Union emission inventory report 1990-2014 under the UNECE Convention on Long-range Transboundary Air Pollution (LRTAP) EEA Report, No 16/2016. ISSN 1977-8449.

2. Quass U, Fermann M, Bröker G. The European dioxin air emission inventory project-final results. Chemosphere 2004;54:1319-1327.

https://doi.org/10.1016/S0045-6535(03)00251-0

3. Lee R, Coleman P, Jones J, Jones K, Lohmann R. Emission factors and importance of PCDD/Fs, PCBs, PCNs, PAHs and PM10 from the domestic burning of coal and wood in the UK. Environ. Sci. Technol 2005;39:1436-1447.

https://doi.org/10.1021/es048745i

4. Dopico M, Gomez A. Review of the current state and main sources of dioxins around the world. Journal of the Air \& Waste Management Association 2015;65:1033-1049.

https://doi.org/10.1080/10962247.2015.1058869

5. Kulkarni PS, Crespo JG, Afonso CAM. Dioxins sources and current remediation technologies - a review. Environment International 2008;34(1):139-153. https://doi.org/10.1016/j.envint.2007.07.009

6. Mari M, Domingo JL. Toxic emissions from crematories: a review. Environment International 2010;36(1):131-137. https://doi.org/10.1016/j.envint.2009.09.006

7. Tuppurainen K, Halonen I, Ruokojärvi P, Tarhanen J, Ruuskanen J. Formation of PCDDs and PCDFs in municipal waste incineration and its inhibition mechanisms: A review. Chemosphere 1998;36:1493-1511.
https://doi.org/10.1016/S0045-6535(97)10048-0

8. Kollikkathara N, Feng H, Stern E. A purview of waste management evolution: special emphasis on USA. Waste Management 2009;29:974-985.

https://doi.org/10.1016/j.wasman.2008.06.032

9. Wang HC, Chang SH, Hung PC, Hwang JF, Chang, MB. Synergistic effect of transition metal oxides and ozone on PCDD/F destruction. Journal of Hazardous Materials 2009;164:14521459 .

https://doi.org/10.1016/j.jhazmat.2008.09.093

10. Bawkon B. Incineration technologies for managing solid waste. Pollution Engineering 1991; 96.

11. Vilavert L, Nadal M, Schuhmacher M, Domingo J. Long-term monitoring of dioxins and furans near a municipal solid waste incinerator: human health risks. Waste Management \& Research 2012;30(9):908-916.

https://doi.org/10.1177/0734242X12453974

12. Rovira J, Vilavert L, Nadal M, Schuhmacher M, Domingo JL. Temporal trends in the levels of metals, PCDD/Fs and PCBs in the vicinity of a municipal solid waste incinerator. Preliminary assessment of human health risks. Waste Management 2015;3:168-175.

https://doi.org/10.1016/j.wasman.2015.05.039

13. Europos parlamento ir tarybos direktyva 2010/75/ES 2010 m. lapkričio $24 \mathrm{~d}$. dèl pramoninių išmetamų teršalų (taršos integruotos prevencijos ir kontrolès).

14. Ghosh RE, Freni-Sterrantino A, Douglas P, Parkes B, Fecht D, de Hoogh K, Fuller G, Gulliver J, Font A, Smith RB, Blangiardo M, Elliott P, Toledano MB, Hansell AL. Fetal growth, still birth, infant mortality and other birth outcomes near UK municipal waste incinerators; retrospective population based cohort and case-control study, Environment International 2019;122:151-158.

https://doi.org/10.1016/j.envint.2018.10.060

15. Li M, Wang C, Cen K, Ni M, Li X. Emission characteristics and vapour/particulate phase distributions of $\mathrm{PCDD} / \mathrm{F}$ in a hazardous waste incinerator under transient conditions. Royal Society Open Science 2018;5(1):1-16.

https://doi.org/10.1098/rsos.171079

16. Bruckmann P, Hiester E, Klees M, Zetzsch C. Trends of $\mathrm{PCDD} / \mathrm{F}$ and $\mathrm{PCB}$ concentrations and depositions in ambient air in Northwestern Germany. Chemosphere 2013; 93:1471-1478. https://doi.org/10.1016/j.chemosphere.2013.07.029

17. Van Den Berg, M. Toxic equivalency factors (TEFs) for PCBs, PCDDs, PCDFs for humans and wildlife. Environmental Health Perspectives 1998;106:775-792. https://doi.org/10.1289/ehp.98106775

18. Gunes G, Saral A. Seasonal variation of PCDD/Fs in the metropolis of Istanbul, Turkey. Environmental Science and Pollution Research International 2014;21(14):8718-8729.

https://doi.org/10.1007/s11356-014-2798-7 
19. Castro-Jimenez J, Mariani G, Vives I, Skejo H, Umlauf G, Zaldivar JM. Atmospheric concentrations, occurrence and deposition of persistent organic pollutants (POPs) in a Mediterranean coastal site (Etang de Thau, France). Environmental Pollution 2011;159 (7):1948-1956.

https://doi.org/10.1016/j.envpol.2011.03.012

20. Wcgiel M, Chrzaszcz R, Maslanka A, Grochowalski A. Study on the impact of industrial flue gases on the PCDD/Fs congener profile in ambient air. Chemosphere 2014;114:76-83.

https://doi.org/10.1016/j.chemosphere.2014.03.104

21. Gusev A, Rozovskaya O, Shatalov V, Aas W, Nizzetto, P. Persistent organic pollutants in the environment. EMEP Status Report 3/2014.

22. United Nations Environment Programe. Standardized Toolkit for Identification and Quantification of Dioxin and Furan Releases Prepared by UNEP Chemicals Geneva, Switzerland, $2005 ; 235$.

23. Lohmann R, Jurado E, Dachs J, Lohmann U, Jones KC. Quantifying the importance of the atmospheric sink for polychlorinated dioxins and furans relative to other global loss processes. J. Geophys. Res 2006.

https://doi.org/10.1029/2005JD006923

24. Environmental Protection Department, Government of Hong Kong Special Administrative Region, 2000. An Assessment of Dioxin Emissions in Hong Kong: Final Report.

25. Vikelsoe J, Andersen HV. Dioxin in Danish air. Organohalogen Compounds 2004;66:2203-2208.

26. Shen H, Guan R, Ding G, Chen Q, Lou X, Chen Z, Zhang L, Xing M, Han J, Wu Y. Polychlorinated dibenzo-p-dioxins/ furans (PCDD/Fs) and polychlorinated biphenyls (PCBs) in Zhejiang foods (2006-2015): Market basket and polluted areas. Science of the Total Environment 2017;574:120-127.

https://doi.org/10.1016/j.scitotenv.2016.09.038

27. Lohmann R, Jones K. Dioxins and furans in air and deposition: a review of levels, behaviour and processes. The Science of the Total Environment 1998;219(1):53-81. https://doi.org/10.1016/S0048-9697(98)00237-X

28. Sorg O. AhR signalling and dioxin toxicity. Toxicology Letters 2014; 230(2):225-233.

https://doi.org/10.1016/j.toxlet.2013.10.039

\section{DISTRIBUTION OF POLYCLORIN DIBENZ-P- DIOXINS AND POLYCLORINES DIBENZOFURANTS IN THE ATMOSPHERIC AIR OF VILNIUS CITY \\ V. Cidzikienė, R. Chadyšienė, P. Miškinis, A. Jukna}

Keywords: anthropogenic processes, polychlorinated dibenzop-dioxins, polychlorinated dibenzofurans, toxic equivalency factor, half-life, diffusion of the organic compound in air.

Summary

Polychlorinated dibenzo-p-dioxins and polychlorinated dibenzofurans (PCDD/F) are toxic organic compounds produced by the combustion of substances in the combustion process and accumulate in the body by subcutaneous fat. The compounds have a relatively long half-life so that winds can transport them in the atmosphere for very long distances from the place of their origin. The worrying rise in the amount of airborne compounds today is already determined by specific testing methods and sensitive devices, but low doses are still difficult to detect in a contaminated environment, food or humans' bodies. The concentration of PCDD/F detected in atmospheric air in Vilnius city was, was $0.03 \mathrm{pg} / \mathrm{m}^{3}$ and $0.016 \mathrm{pg} / \mathrm{m}^{3}$ in May and August of 2017, respectively. In February of 2018, the increase in PCDD/F concentration reached the peak value $0.52 \mathrm{pg} / \mathrm{m}^{3}$ and again dropped down $0.015 \mathrm{pg} / \mathrm{m}^{3}$ in October 2018. The variations of the PCDD/F concentration in Vilnius City well correlate with concentrations determined in Western European countries. Under current EU and Republic of Lithuania legislation, the annual limit value for PCDD/F pollutant should not exceed $100 \mathrm{pg} / \mathrm{m}^{3}$, but there is still no daily limit value for these toxic compounds in national or EU directives. The recommended value by the World Health Organization (WHO) is $3 \cdot 10^{6} \mathrm{pg} / \mathrm{m}^{3}$. Our experimental and theoretical modeling studies allow us to evaluate the current concentration of $\mathrm{PCDD} / \mathrm{F}$ compounds in the atmospheric air of Vilnius city and to predict their change, considering the emergence of new sources of pollution.

Correspondence to: vigilija.cidzikiene@vgtu.lt

Gauta 2019-05-19 